\title{
Pruning intensity and fruit load influence vegetative and fruit growth in an early-maturing peach tree (cv. Alexandra)
}

\author{
Claude BussI $^{a *}$, Françoise LeSCOURRET ${ }^{b}$, Michel GeNARD ${ }^{b}$, Robert HABIB ${ }^{b}$
}

a Inra-UERI, Domaine de Gotheron, 26320 St. Marcel-les-Valence, France

b Inra-PSH, Centre de recherche d'Avignon, 84140 Montfavet, France

Claude.Bussi@avignon.inra.fr

* Correspondence and reprints

Received 13 September 2004 Accepted 2 February 2005

Fruits, 2005, vol. 60, p. 133-142 (C) $2005 \mathrm{Cirad} /$ EDP Sciences All rights reserved DOI: 10.1051/fruits:2005017

RESUMEN EsPaÑoL, p. 142

\section{Pruning intensity and fruit load influence vegetative and fruit growth in an early-maturing peach tree (cv. Alexandra).}

Abstract - Introduction. The distribution of shoots and fruits in the tree is an important consideration to improve peach cropping. Therefore, the effects of intensity of pruning were investigated for two years in trees with the same fruit load and, the following year, in trees with different fruit loads. Materials and methods. In an early-maturing peach orchard (cv. Alexandra), three pruning intensities were applied for three years: light, medium and severe. The first two years, the same fruit load was applied for the different pruning treatments; in the last year, three fruit loads per tree were tested: low, intermediate and high. Results and discussion. Increasing severity of pruning stimulated average fruit weight and fruit diameter, limiting (2nd year) or not (3rd year) fruit yield. Severe pruning also tended to enhance young shoot growth on the shoot bearing fruit and on the scaffold branch. Fruit diameter improvement with severe pruning might be therefore explained by the increase in vegetative growth likely to enhance available assimilates for fruit growth. However, severe pruning could favor an alternation in flower setting, as observed in the 2nd year. Increasing fruit load stimulated fruit yield, but, with the highest fruit load, no significant fruit yield enhancement was detected compared with the intermediate fruit load. On the contrary, average fruit weight and fruit soluble solids always decreased with increasing fruit load. Conclusion. Intensity of pruning and fruit load must be well adapted to ensure an appropriate peach production; excessive pruning and fruit load of an early-maturing peach cultivar should be avoided in order not to limit fruit yield and quality, respectively.

France / Prunus persica / pruning / growth / production / fruit / quality

Influence de l'intensité de la taille et de la charge en fruits sur les croissances végétative et fructifère d'un pêcher précoce (cv. Alexandra).

Résumé - Introduction. Pour la production de pêches, la répartition des rameaux et des fruits sur l'arbre est importante à considérer. Par conséquent, les effets de l'intensité de la taille ont été étudiés pendant deux ans sur des arbres ayant une même charge en fruits et, l'année suivante, sur des arbres ayant différentes charges en fruits. Matériel et méthodes. Dans un verger de pêchers précoces (cv. Alexandra), trois intensités de taille ont été appliquées pendant trois ans légère, intermédiaire et sévère. Pour les deux premières années, une même charge fruitière a été appliquée pour les différents traitements de taille ; pour la dernière année, trois charges en fruit par arbre ont été testées : faible, moyenne et élevée. Résultats et discussion. La sévérité de la taille a stimulé le poids moyen et le diamètre du fruit, limitant ( $2^{\mathrm{e}}$ année $)$ ou non $\left(3^{\mathrm{e}}\right.$ année $)$ le rendement en fruits de l'arbre. La taille sévère a également favorisé la croissance des jeunes pousses sur le rameau porteur de fruits et sur la charpentière. L'augmentation du diamètre du fruit provoquée par la taille sévère pourrait ainsi s'expliquer par l'amélioration de la croissance végétative susceptible d'augmenter la disponibilité en assimilats pour la croissance du fruit. Cependant, la taille sévère pourrait favoriser l'alternance, comme observé la $2^{\mathrm{e}}$ année. L'accroissement de la charge en fruits a stimulé le rendement, mais, avec la plus forte charge, il n'y a pas eu d'augmentation significative du rendement par rapport à la charge moyenne. À l'opposé, le poids moyen du fruit et sa teneur en sucres solubles a toujours diminué en même temps que l'accroissement de la charge en fruits. Conclusion. L'intensité de la taille, ainsi que la charge en fruits des arbres doivent être bien adaptées afin d'assurer une production fruitière appropriée. Une taille et une charge en fruits excessives devront être évitées pour la production d'une pêche précoce de façon à ne pas limiter, respectivement, le rendement et la qualité des fruits.

France / Prunus persica / taille / croissance / production / fruit / qualité 


\section{Introduction}

Fruit thinning is usually performed in orchards in order to improve fruit size [1, 2]. Actually, crop load has been pointed out as the main factor of fruit size variation in apple [3] and peach $[4,5]$. The principal aim of thinning is thus to optimize the leaf-to-fruit ratio [6] Furthermore, for a given crop load, different factors may influence the fruit size and quality. The light environment in the peach tree canopy appears determinant, shade contributing to decreasing fruit growth [7-10]. Moreover, shoots contribute to fruit quality according to their type [11]: the major source of newly synthesized carbohydrates for peach growth seems to be lateral shoots, when actively growing extension shoots preferentially support their vegetative growth before fruit growth. Cultural practices which limit shade and promote lateral shoot growth in the canopy should therefore improve peach quality.

The light environment and shoot type partitioning within the tree mostly depend on tree pruning [12-14]. For peach trees, we made the hypothesis that, for a given crop load (i.e., a constant thinning level of the whole tree), modifying the number of shoots bearing fruit by pruning would modulate fruit growth and quality. By limiting shade and improving the nutrient supply to shoots by the roots [15], severe pruning should contribute to increasing young shoot and peach growth; this assumption had to be checked. We proposed to perform experiments for three years in order to test the effects of intensity of pruning on vegetative and fruit growth of peach trees for an average fruit load on the whole tree, and lastly for different fruit loads.

For these experiments, an early-maturing peach cultivar (Alexandra) was chosen because (i) vegetative and fruit growth of these peaches take place at the same time, and are likely to compete with each other [16], and (ii) their fruit quality is most often reported to be low, thus requiring improvement [17]. To compare the different treatments applied, vegetative growth, flower and fruit development were assessed, with fruit total soluble solids at harvest.

\section{Materials and methods}

\subsection{Plant materials and experimental design}

The study was carried out in a peach tree orchard (cv. Alexandra on GF 305 rootstock) planted in 1998, at the Gotheron Experimental Station of the French Institut National de la Recherche Agronomique (INRA) near Valence in the Middle Rhône Valley in France. The soil was stony alluvial with 15\% clay, 30\% silt and 54\% sand, considered particularly suitable for peach tree cropping [18]. The plantation was composed of four rows of 33 trees: the trees were spaced $2 \mathrm{~m}$ apart in the row, with the rows $4.5 \mathrm{~m}$ apart. The number of main scaffold branches per tree was 2 ('Y' training) [19]. All the trees received routine horticultural care, except for pruning and thinning, which varied according to the treatments. Peaches were pruned in winter and hand-thinned at the beginning of May [20].

The experiments were performed on the two middle tree rows, the two external rows being taken as guard rows. The homogeneity of the experimental area was maintained by sowing cereal crops for three successive years before planting, and was checked by measuring tree trunk circumferences before the differentiation of the treatments: trunk cross areas were not detected to be different (results not shown). In 2000, at the differentiation of the treatments for the first experiment, trees of the same row were sampled (figure 1). Each of the three treatments was disposed in height blocks, these blocks being separated from each other by a guard tree. In 2002, three blocks of seven treatments were sampled on the second experimental tree row for the second experiment (figure 1).

\subsection{Experimental treatments}

In the first two years of the first experiment, three intensities of pruning were compared with the same fruit load on the tree. In the third year, for the second experiment, three intensities of pruning were also performed, but each with different fruit loads so as to evaluate the two cropping factors better: pruning and thinning (table I). 
In the first experiment, a fruit load was chosen every year prior to experimentation; pruning intensities were light, medium or severe. In the second experiment, the same pruning intensities were applied, but with a low or an intermediate fruit load per tree; an overload was also tested, but only for the light pruning.

\subsection{Measurements}

All the 1-year-old shoots (in spring 2001) or 15 of these shoots (in spring 2002 and 2003) were chosen (equivalent in length for the different treatments) on the main scaffold branches orientated east, at the beginning of the growing season. The number of flower buds and young fruits were checked, in order to estimate the effects of the treatments. The fruits were picked at their maximum growth, so as to evaluate their quality. For the first experiment, all fruits from each tree were weighed at harvest in 2000 and 2001. In 2002, for the second experiment, only fruits of one scaffold branch (orientated east), i.e., half of the tree, were weighed at harvest. Moreover, fruit diameters were recorded, so as to determine fruit grade partitioning for each treatment. Soluble solid percentages were also determined for each fruit picked using a refractometer, to evaluate peach taste quality.

Kinetics of the vegetative growth were assessed in 2001 by measuring lengths of young shoots every 2 weeks. We measured all the young shoots, firstly, directly inserted into one scaffold branch of the tree (young shoot length on branch) and, secondly, growing on five sampled shoots bearing fruits per tree (young shoot length per shoot). The dates of measurement were expressed in number of days after bloom (DAB). Moreover, on the 11 July, total young shoot growth (on the branch and on the shoot) was evaluated on half-trees for the three pruning treatments, with two replications for each.

\subsection{Statistical analysis}

A classical analysis of variance was used for the statistical analysis of these data [21]. The Newman-Keuls test was performed for average discrimination. Fruit grade partitioning

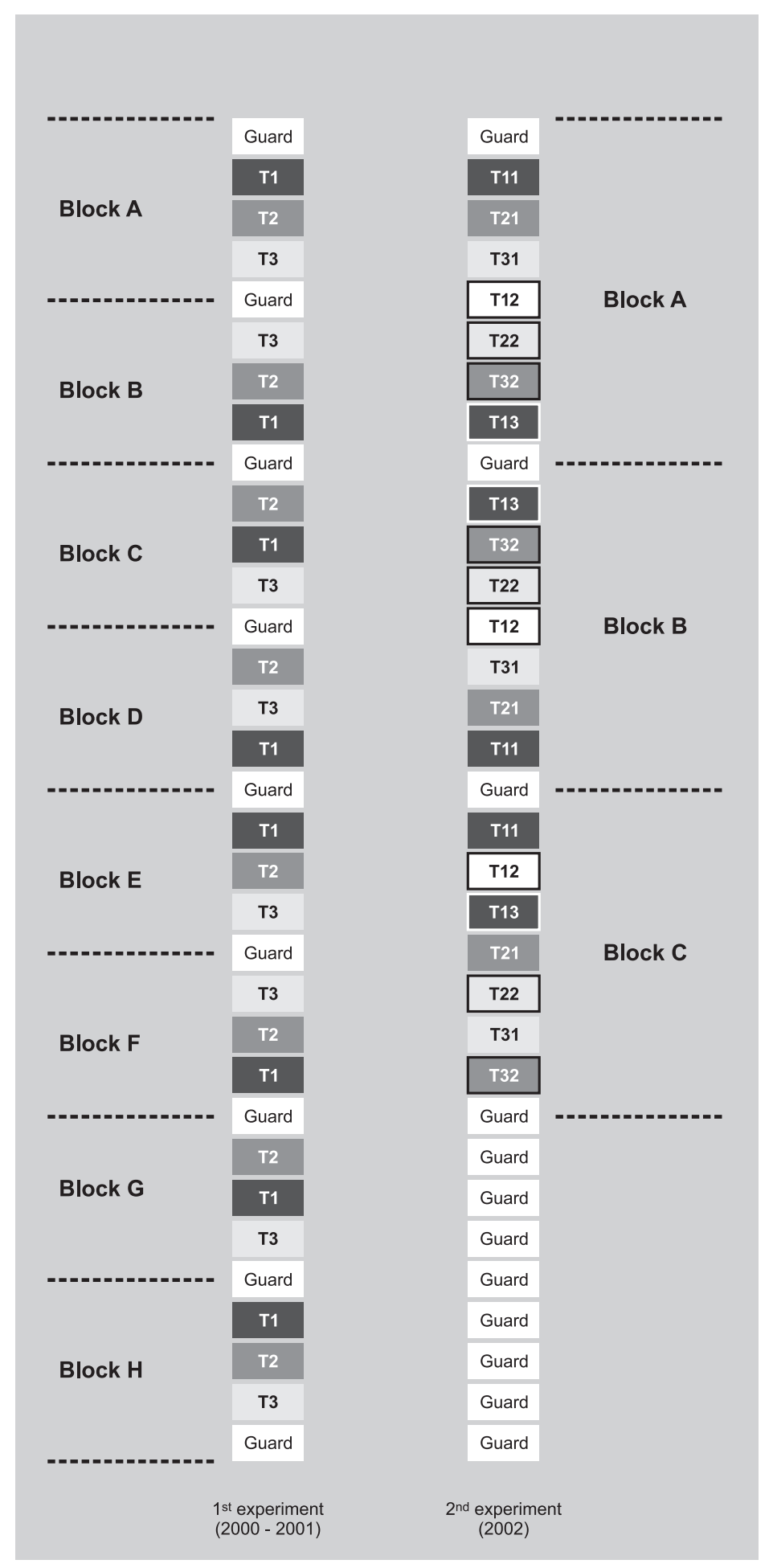

Figure 1.

Experimental layout in experiments I and II. Each tree is represented by a rectangle (dotted for guard trees). 
Table I.

Pruning and thinning treatments in peach trees (cv. Alexandra). The numbers of fruits per tree were determined prior to the experiment. The numbers of fruits actually obtained are given in the following tables.

\begin{tabular}{lccccccccc} 
& \multicolumn{2}{c}{ Treatments } & \multicolumn{2}{c}{ Number of shoots per tree } & \multicolumn{3}{c}{ Number of fruits per tree } \\
\hline $\begin{array}{l}2000 \\
\text { (8 replications) }\end{array}$ & $\begin{array}{c}2001 \\
\text { (8 replications) }\end{array}$ & $\begin{array}{c}2002 \\
\text { (3 replications) }\end{array}$ & 2000 & 2001 & 2002 & 2000 & 2001 & 2002 \\
\hline T1 & T1 & T11 & 40 & 90 & 120 & 100 & 180 & 60 \\
T2 & T2 & T21 & 30 & 45 & 90 & 100 & 180 & 60 \\
T3 & T3 & T31 & 20 & 30 & 60 & 100 & 180 & 60 \\
- & - & T12 & - & - & 120 & - & - & 270 \\
- & - & T22 & - & - & 90 & - & - & 270 \\
- & - & T32 & - & - & 60 & - & - & 270 \\
- & - & T13 & - & - & 120 & - & - & 420
\end{tabular}

Table II.

Flowers and fruits in 2000 and 2001 for peach trees (cv. Alexandra) subjected to pruning (number of shoots per tree) treatments according to table $I$.

\begin{tabular}{|c|c|c|c|c|c|c|c|c|}
\hline Year & Treatment & $\begin{array}{l}\text { Number of young fruit / } \\
\text { m shoot length } \\
\text { (April 2001) }\end{array}$ & $\begin{array}{l}\text { Number of fruits } \\
\text { per tree at } \\
\text { harvest }\end{array}$ & $\begin{array}{l}\text { Fruit-to- } \\
\text { shoot ratio } \\
\text { at harvest }\end{array}$ & $\begin{array}{l}\text { Yield per } \\
\text { tree } \\
(\mathrm{kg})\end{array}$ & $\begin{array}{l}\text { Average fruit } \\
\text { weight } \\
\text { (g) }\end{array}$ & $\begin{array}{l}\text { Total soluble } \\
\text { solids } \\
\text { (\%) }\end{array}$ & $\begin{array}{l}\text { Number of flower buds / } \\
\text { m shoot length } \\
\text { (March 2002) }\end{array}$ \\
\hline \multirow[t]{3}{*}{2000} & T1 & - & 104 & 2.6 & 13.8 & 132.5 & $11.9 \mathrm{a}$ & - \\
\hline & T2 & - & 105 & 3.5 & 14.3 & 135.9 & $11.6 \mathrm{ab}$ & - \\
\hline & T3 & - & 115 & 5.8 & 15.0 & 130.1 & $11.3 \mathrm{~b}$ & - \\
\hline \multirow[t]{3}{*}{2001} & $\mathrm{~T} 1$ & $12.0 \mathrm{a}$ & $139 a$ & 1.5 & $19.8 \mathrm{a}$ & $144.0 \mathrm{~b}$ & 10.4 & 59 \\
\hline & T2 & $10.4 \mathrm{ab}$ & $53 \mathrm{~b}$ & 1.2 & $8.4 \mathrm{~b}$ & $159.0 \mathrm{a}$ & 10.5 & 61 \\
\hline & T3 & $7.4 \mathrm{~b}$ & $46 \mathrm{~b}$ & 1.5 & $7.3 \mathrm{~b}$ & $158.0 \mathrm{a}$ & 10.7 & 59 \\
\hline
\end{tabular}

Data followed by different letters were significantly different at $P=0.05$. The letters refer to the comparisons between the different treatments for each year.

was compared for the different treatments using a chi-square test (Statgraphics ${ }^{\circledR}$ Plus software).

\section{Results}

\subsection{Flowers and young fruits}

The number of young fruits was evaluated in spring 2001, and that of flower buds in spring 2002 and 2003 (tables II, III). The number of young fruits per meter shoot length varied between 7 and 12 in 2001, appearing very low compared with the number of flower buds in spring of the following year, varying between 59 and 61 per meter shoot length (table II). In spring 2003 , the number of flower buds per meter shoot length was once more rather low, varying between 12 and 26 (table III). Such differences between years were probably due to climatic conditions, as already mentioned [22]. Frost actually affected the experimental orchard in the springs of 2001 and 2003. Negative temperatures under cover were registered: $-3.5^{\circ} \mathrm{C}$ at the pink bud stage in 2001 and $-1{ }^{\circ} \mathrm{C}$ at full bloom in 2003 . 


\begin{tabular}{|c|c|c|c|c|c|c|}
\hline Treatment & $\begin{array}{c}\text { Number of fruits per } 1 / 2 \text { tree } \\
\text { at harvest }\end{array}$ & $\begin{array}{c}\text { Fruit-to-shoot } \\
\text { ratio } \\
\text { at harvest }\end{array}$ & $\begin{array}{l}\text { Yield per } 1 / 2 \\
\text { tree } \\
(\mathrm{kg})\end{array}$ & $\begin{array}{l}\text { Average fruit } \\
\text { weight } \\
\text { (g) }\end{array}$ & $\begin{array}{l}\text { Total soluble } \\
\text { solids } \\
(\%)\end{array}$ & $\begin{array}{c}\text { Number of flower buds / } \\
\text { m shoot length } \\
\text { (March 2003) }\end{array}$ \\
\hline T11 & $43 c$ & 0.7 & $6.8 \mathrm{c}$ & $157.8 b$ & $10.2 \mathrm{a}$ & $25.0 \mathrm{a}$ \\
\hline $\mathrm{T} 21$ & $36 \mathrm{c}$ & 0.8 & $5.9 c$ & $164.4 \mathrm{~b}$ & $10.6 \mathrm{a}$ & - \\
\hline T31 & $36 \mathrm{c}$ & 2.4 & $6.4 \mathrm{c}$ & $177.4 \mathrm{a}$ & $9.9 \mathrm{a}$ & $26.1 a$ \\
\hline $\mathrm{T} 12$ & $104 \mathrm{~b}$ & 1.7 & $14.3 \mathrm{~b}$ & $132.1 \mathrm{dc}$ & $9.1 \mathrm{~b}$ & $24.1 \mathrm{ab}$ \\
\hline T22 & $134 \mathrm{~b}$ & 3.0 & $17.0 \mathrm{ab}$ & $126.2 \mathrm{~d}$ & $8.8 b$ & - \\
\hline T32 & $125 b$ & 4.2 & $17.2 \mathrm{ab}$ & $138.2 \mathrm{c}$ & $8.7 b$ & $17.4 \mathrm{~b}$ \\
\hline T13 & $180 \mathrm{a}$ & 3.0 & $18.7 \mathrm{a}$ & $105.5 \mathrm{e}$ & $8.6 \mathrm{~b}$ & $12.9 \mathrm{c}$ \\
\hline
\end{tabular}

In spring 2001, the number of young fruits per meter shoot length was significantly higher with light pruning (T1) than with severe pruning (T3) (table II). In spring 2003, the number of flower buds per meter shoot length also decreased after severe pruning in 2002, but only for the treatment with 270 fruits per tree in 2002 (table III). In fact, flower buds and young fruit densities on the shoots bearing fruit appeared to decrease with increasing fruit-to-shoot ratios of the previous year. These densities generally decreased when the measured fruit-toshoot ratios were higher than 3 in the previous year. In spring 2002, flower densities did not differ with pruning treatments, but, in 2001, the fruit-to-shoot ratios were equivalent and did not exceed 1.5.

\subsection{Fruit at harvest}

In 2000 and 2002, the number of fruits per tree at harvest was in accordance with the expected number for each treatment (tables II, III), but it differed in 2001: the expected number was 180 , and it reached 139 with T1, but only 53 and 46 with T2 and T3. Thus, in 2001, yield decreased with higher intensity of pruning; the highest fruit yield and the lowest average fruit weight being achieved with light pruning (T1) (table II). However, in 2002, severe pruning stimulated average fruit weight compared with light pruning, without limiting fruit yield (table III). As a result, fruit grade partitioning was also significantly improved by severe pruning (figure $2 A$ ). No soluble solids variations were significant with pruning intensities, for the same fruit load on the whole tree (table III).

Increasing fruit load stimulated fruit yield (from $5.9 \mathrm{~kg}$ per tree with 60 fruits to $18.7 \mathrm{~kg}$ per $1 / 2$ tree with 420 fruits), but, above 270 fruits per tree, no significant fruit yield enhancement was detected anymore (table III). On the contrary, average fruit weight significantly decreased from 60 to 270 fruits per tree (158 to 132) g, and from 270 to 420 fruits per tree (132 to $105 \mathrm{~g}$ ); these tendencies were confirmed by fruit grade partitioning (figure $2 B$ ). Fruit grades higher than grade $\mathrm{B}$, i.e., with the highest marketable value, were the most represented with 60 fruits per tree (figure $2 B$ ). However, because of higher yields, 270 fruits per tree appeared to be the most economically interesting fruit load treatment. In parallel, fruit soluble solids decreased with increasing fruit load $(10.2 \%$ with 60 fruits to $8.6 \%$ with 420 fruits) (table III).

\subsection{Vegetative growth}

In 2001, young shoot lengths tended to reach their maximum on the last date of measurement, i.e., at the beginning of July (figure $3 A$ ). Young shoot lengths on the shoots bearing fruit were significantly higher with severe 
Figure 2.

Peach grade partitioning versus intensity of pruning $(A)$ and fruit load (B) in 2002.

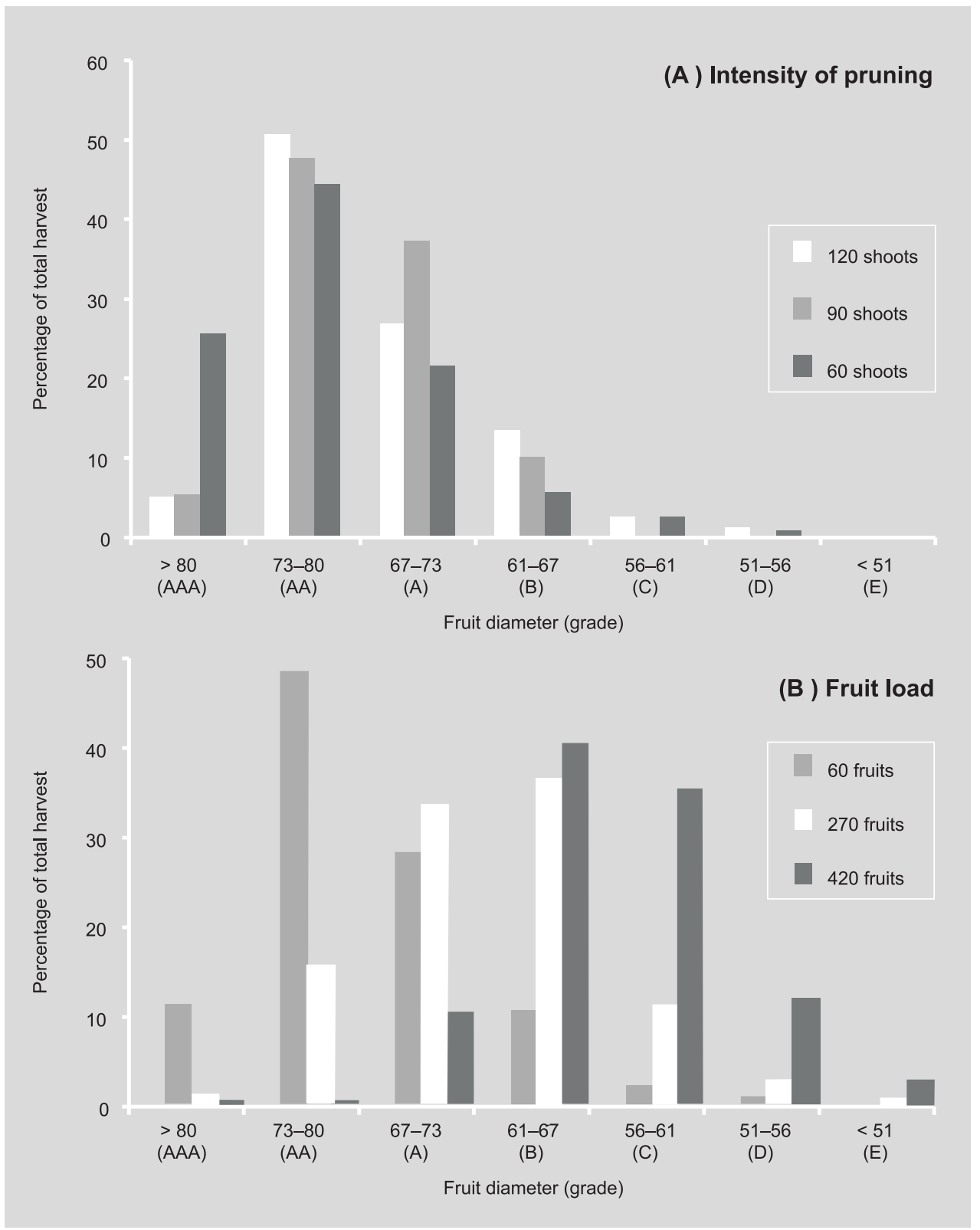

pruning compared with light pruning on the first three dates of measurement. Because of a lack of replications, no statistical test was undertaken with young shoot lengths on the scaffold branch (figure 3B); nevertheless, they followed the same trend as young shoot lengths on the shoots bearing fruit, as they were $c a .25 \mathrm{~m}$ long with severe pruning against $10 \mathrm{~m}$ long with light pruning.
These results were confirmed by total as they tended to increase with the severity of pruning (figure 4). Total young shoot lengths were higher on the shoots bearing fruit than on the scaffold branch. Moreover, considering each replication for T1 and T2, a weaker vegetative growth on the shoot bearing fruit was generally associated with young shoot lengths measured on the 11 July, 


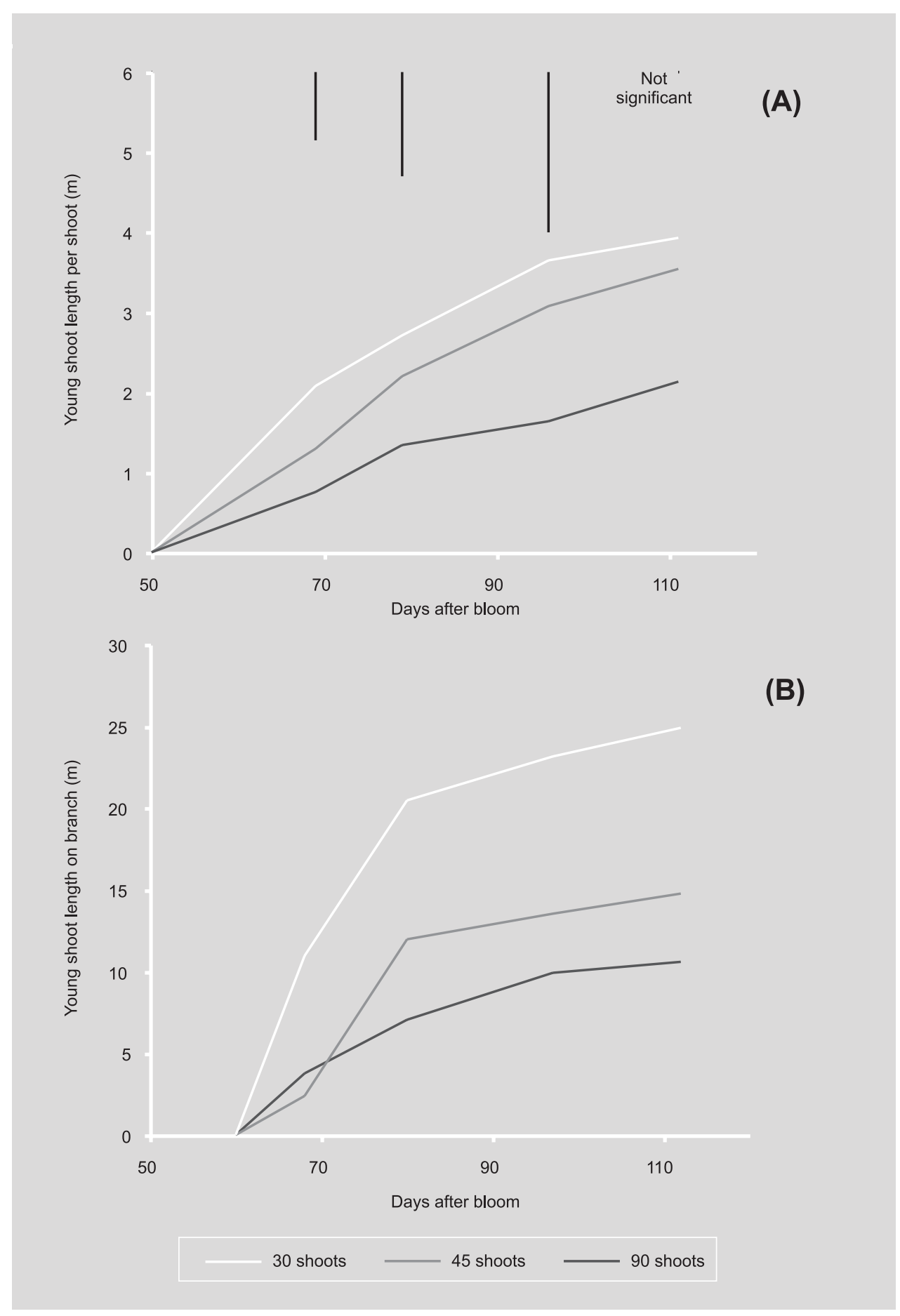

Figure 3.

Lengths of young shoots growing on a shoot bearing fruit (A) and directly inserted into a branch $(B)$ versus the intensity of pruning in 2001 (see table I for the legend).

Vertical bars denote NewmanKeuls' maximum confidence intervals for the different treatments at $P=0.05$.

a higher vegetative growth on the scaffold branch of the same tree (figure 4), so as to equilibrate total growth of the whole tree [23].

\section{Discussion}

With increasing pruning intensities, vegetative growth globally increased (figures 3, 4), 


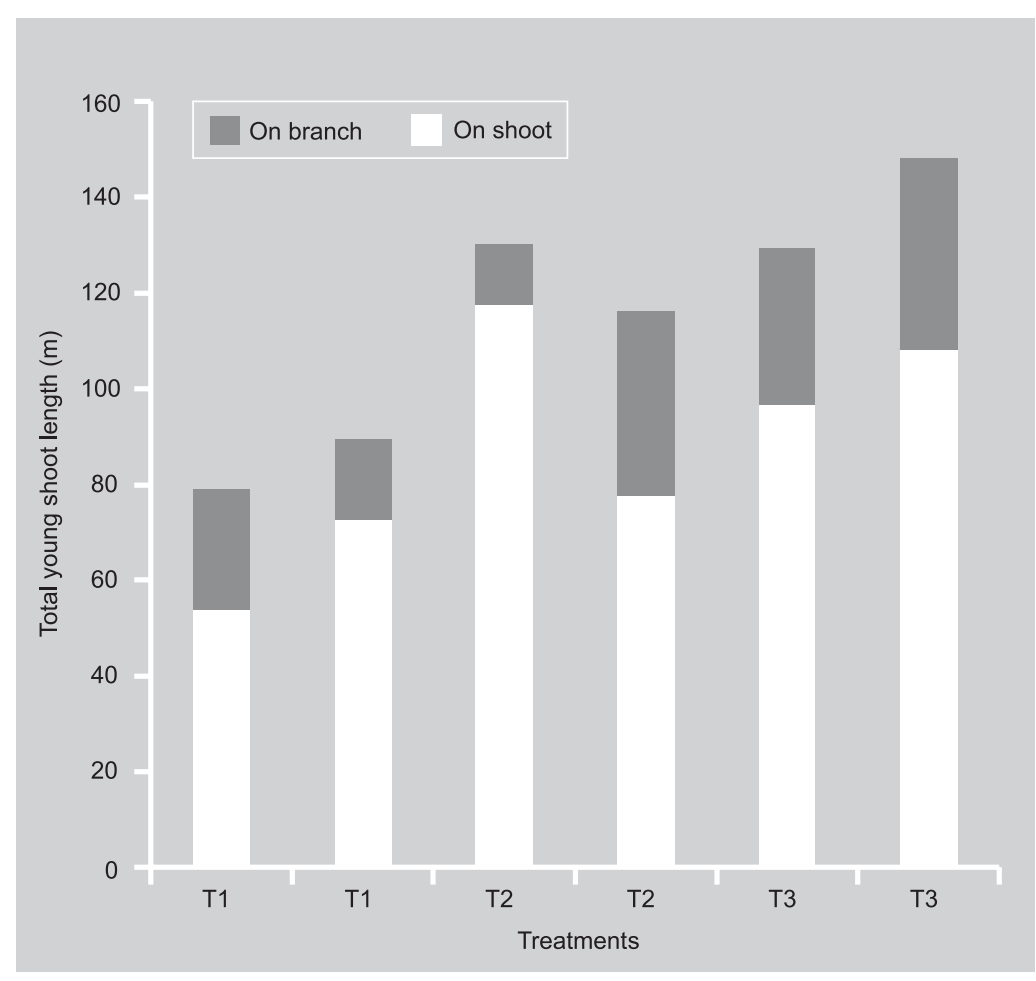

Figure 4.

Total length of the young shoots grown on a scaffold branch in 2001.

Two trees per treatment were sampled on the 11 July (table I). probably due to an optimization of the light environment inside the tree likely to promote photosynthesis rates [10, 12, 24, 25]. Moreover, the lower number of shoots bearing fruit with severe pruning could improve the distribution within aerial parts of the tree of available mineral elements supplied by the roots [15]. The induced stimulation of vegetative growth might therefore be considered as a recovery to reach the initial (before pruning) shoot-to-root ratio of the whole tree [26, 27]. This regulation of the vegetative growth was pointed out as a direct effect of the root functioning [28].

Vegetative growth enhancement caused by severe pruning was likely to stimulate the leaf-to-fruit ratio compared with light pruning for the same fruit load on the trees. Consequently, the amounts of assimilates available for fruit growth should be increased with severe pruning [29], which probably explained the higher fruit growth observed in that case in 2002 (table III). Thus, compared with light pruning with the same fruit load, severe pruning appeared well-suited to promoting heavier fruits and higher fruit grades (figure $2 A$ ). This effect contributed to improving the fruits' marketable value, without altering their soluble solid percentages (table III).

However, a reduction of yield was detected in 2001, and it was particularly accentuated with severe pruning compared with light pruning (table II). This trend was also observed at the end of the second experiment as flower bud densities tended to decrease with severe pruning in March 2003 (table III), suggesting an alternation in flower setting. Two assumptions may be proposed. Firstly, the replenishing reserves in the leafy shoots of peach trees were already shown to be reduced with significant uptake of assimilates by the fruits [30], and, precisely, severe pruning induced the highest fruit-to-shoot ratios for a given total fruit load (tables II, III). Secondly, high vegetative growths, as induced by severe pruning, correspond with the presence in the shoots of gibberellins [31], hormones that inhibit flower induction in the peach tree [12]. In summary, the intensity of pruning with an early peach cultivar should be significant enough to improve the light environment and vegetative growth, which both increase the fruit growth, but overpruning should be avoided in order not to favor an alternation in flower setting.

Concerning fruit load, 420 fruits per tree constituted an overload, as they did not induce an increase in fruit yield, compared with 270 fruits per tree, while average fruit weight and soluble solids percentage were reduced (table III). The highest fruit grades were obtained with 270 fruits per tree, conferring the highest marketable value on this treatment compared with 420 fruits (figure $2 B$ ). This result cannot be explained by competition between fruits for their growth at the level of the shoot bearing fruit, as the measured fruit-to-shoot ratio was lower with 420 fruits and 120 shoots (3.0) than with 270 fruits and 60 shoots (4.2). Competition between fruits at the level of the whole tree or between fruits and roots have to be considered [3, 32]. Notably, long-distance transport of assimilates within the tree should be assessed with further experiments, including isolation of the shoot bearing fruit by girdling [33]. Finally, tree fruit load has to be large enough to ensure an appropriate level 
of production, but an excessive fruit load must be avoided because it reduces fruit quality.

\section{Acknowledgements}

The authors are indebted to INRA for its financial support ("Integrated Fruit Production" project, contract No. P00232) and to J. Besset and T. Girard for their technical assistance.

\section{References}

[1] Corelli-Grappadelli L., Coston D.C., Thinning pattern and light environment in peach tree canopies influence fruit quality, HortScience 26 (1991) 1464-1466.

[2] Pavel E.W., DeJong T.M., Source- and sinklimited growth periods of developing peach fruits indicated by relative growth rate analysis, J. Am. Soc. Hortic. Sci. 118 (6) (1993) 820-824.

[3] Volz R.K., Ferguson I.B., Bowen J.H., Watkins C.B., Crop load effects on fruit mineral nutrition, maturity, fruiting and tree growth of 'Cox's Orange Pippin apple, J. Hortic. Sci. 68 (1) (1993) 127-137.

[4] Marini R.P., Sowers D.L., Peach fruit weight is influenced by crop density and fruiting shoot length but not position on the shoot, J. Am. Soc. Hortic. Sci. 119 (2) (1994) 180-184.

[5] Blanco A., Pecquerul A., Val J., Monge E., Gomez Aparisi J., Crop-load effects on vegetative growth, mineral nutrient concentration and leaf water potential in 'Catherine' peach, J. Hortic. Sci. 70 (4) (1995) 623-629.

[6] Sansavini S., Corelli L., Giunchi L., Peach yield efficiency as related to tree shape, Acta Hortic. 173 (1985) 139-158.

[7] Kappel F., Flore J.A., Effects of shade on photosynthesis, specific leaf weight, leaf chlorophyll content, and morphology of young peach trees, J. Am. Soc. Hortic. Sci. 108 (1983) 541-544.

[8] Flore J.A., Lakso A.N., Environmental and physiological regulation of photosynthesis in fruit crops, Hortic. Rev. 11 (1989) 111-157.

[9] Tustin S., Corelli-Grappadelli L., Ravaglia G., Effect of previous-season and current light environments on early-season spur development and assimilate translocation in 'Golden
Delicious' apple, J. Hortic. Sci. 67 (3) (1992) 351-360.

[10] Chartzoulakis K., Therios I., Noitsakis B., Effects of shading on gas exchange, specific leaf weight and chlorophyll content in four kiwifruit cultivars under field conditions, J. Hortic. Sci. 68 (4) (1993) 605-611.

[11] Corelli-Grappadelli L., Ravaglia G., Asirelli A., Shoot type and light exposure influence carbon partitioning in peach cv. Elegant Lady, J. Hortic. Sci. 71 (4) (1996) 533-543.

[12] Marini R.P., Vegetative growth, yield, and fruit quality of peach as influenced by dormant pruning, summer pruning, and summer topping, J. Am. Soc. Hortic. Sci. 110 (1985) 133-139.

[13] Bussi C., Defrance H., Atger P., Optimisation d'un verger de pêchers. Choix du matériel et des techniques culturales, Arboric. Fruit. 384 (1986) 51-55.

[14] Li S.H., Zhang X.P., Meng Z.Q., Wang X., Response of peach trees to modified pruning. 1. Vegetative growth. 2. Cropping and fruit quality, New Zeal. J. Crop Hort. 22 (1994) 401-417.

[15] Cannell M.G.R., Kimeu B.S., Uptake and distribution of macronutrients in trees of Coffea arabica in Kenya as affected by seasonal climatic differences and the presence of fruits, Ann. Appl. Biol. 68 (1985) 213-230.

[16] DeJong T.M., Doyle J.F., Day K.R., Seasonal patterns of reproductive and vegetative sink activity in early and late maturing peach cultivar, Physiol. Plantarum 71 (1987) 83-88.

[17] Giauque P., Desbrus D., Pêche : qualité au verger et maîtrise de la main d'œuvre, Réussir Fruits et Légumes 197 (2001) 27-30.

[18] Bornand M., Étude pédologique dans la vallée du Rhône, Centre de recherches agronomiques du Midi, Inra éd., Montpellier, France, 1968.

[19] Clauzel G., Pollien J.M., Signoret V., La taille du pêcher, Int. note, INRA, Valence, 1986, 25 p.

[20] Mitcham E., Thinned peaches are big peaches, Fruit Grow. 9 (1980).

[21] Dagnelie P., Théorie et méthodes statistiques, Vol. II, 2nd Ed., Les presses agronomiques de Gembloux, Gembloux, Belgique, 1975.

[22] Bussi C., Huguet J.G., Besset J., Girard T., The consequences of cultural practices on growth and cropping of peach trees subjected to localized irrigation: effects of soil management, nitrogen fertilization and tree density, J. Hortic. Sci. 69 (5) (1994) 905-914. 
[23] Kervella J., Pagès L., Génard M., Growth context and fate of axillary meristems of young peach trees. Influence of parent shoot growth characteristics and of emergence date, Ann. Bot. 76 (1995) 559-567.

[24] Genard M., Lescourret F., Ben Mimoun M., Besset J., Bussi C., A simulation model of growth at the shoot-bearing fruit level. II. Test and effect of source and sink factors in the case of peach, Eur. J. Agron. 9 (1998) 189-202.

[25] DeJong T.M., Day K.R., Relationship between shoot productivity and leaf characteristics in peach canopies, HortScience 26 (10) (1991) 1271-1273.

[26] Williamson J.G., Coston D.C., The relationship among root growth, shoot growth, and fruit growth of peach, J. Am. Soc. Hortic. Sci. 114 (2) (1989) 180-183.

[27] Blasing D., Atkinson D., Clayton-Greene K., The contribution of roots and reserves to tree nutrient demand: implication for the interpretation of analytical data, Acta Hortic. 274 (1990) 51-69.

[28] Dann I.R., Wildes R.A., Chalmers D.J., Effects of limb girdling on growth and devel- opment of competing fruit and vegetative tissues of peach trees, Austral. J. Plant Physiol. 11 (1984) 49-58.

[29] Ferree D.C., Palmer J.W., Effects of spur defoliation and ringing during bloom and fruiting, fruit mineral level and net photosynthesis of 'Golden Delicious' apple, J. Am. Soc. Hortic. Sci. 107 (1982) 1182-1186.

[30] Lescourret F., Ben Mimoun M., Genard M., A simulation model of growth at the shootbearing fruit level I. Description and parameterization for peach, Eur. J. Agron. 9 (1998) 173-188.

[31] Li S.H., Bussi C., Hugard J., Clanet H., Critical period of flower bud induction in peach trees associated with shoot length and bud position, Gartenbauwiss. 54 (2) (1989) 4953.

[32] Wright C.J., Interactions between vegetative and reproductive growth, in: Wright C.J. (Ed.), Manipulation of fruiting, Butterworths, London, UK, 1989, 15-27.

[33] Ben Mimoun M., Longuenesse J.J., Genard M., $P$ max as related to leaf:fruit ratio and fruit assimilate demand in peach, J. Hortic. Sci. 71 (5) (1996) 767-775.

Influencia de la intensidad del tamaño y de la carga de frutas en el crecimiento vegetativo y fructífero de un melocotonero precoz (cv. Alexandra).

Resumen - Introducción. Para la producción de melocotones, es importante considerar la distribución de ramas y de frutas del árbol. Por ello durante 2 años se estudiaron los efectos de la intensidad del tamaño sobre árboles con una misma carga de frutas y, al año siguiente, sobre árboles con cargas de frutas distintas. Material y métodos. En una huerta de melocotoneros precoces (cv Alexandra), se aplicaron tres intensidades del tamaño durante 3 años: ligera, intermedia y pesada. Para los dos primeros años, se aplicó una misma carga de frutas en los distintos tratamientos del tamaño; para el último año, se testaron tres cargas de frutas por árbol: floja, media y elevada. Resultados y discusión. La magnitud del tamaño estimuló el peso medio y el diámetro del fruto, limitando ( $2^{\circ}$ año) o no $\left(3^{\circ}\right.$ año) el rendimiento de los frutos del árbol. El tamaño importante favoreció también el crecimiento de los nuevos brotes tanto en la rama portadora del fruto como en la rama principal lateral. El aumento del diámetro del fruto causado por el tamaño importante podría entonces explicarse por la mejora del crecimiento vegetativo susceptible de aumentar la disponibilidad en asimilados para el crecimiento del fruto. Sin embargo, el tamaño importante podría favorecer la alternancia, como se observa en el $2^{\circ}$ año. El aumento de la carga de frutas estimuló el rendimiento, pero, con la carga más alta, no hubo ningún aumento significativo del rendimiento con relación a la carga media. Al contrario, el peso medio del fruto y su contenido en azúcares solubles disminuyó siempre al mismo tiempo que el aumento de la carga en frutas. Conclusión. Se deben adaptar apropiadamente la magnitud del tamaño y la carga de frutas de los árboles con el fin de garantizar así una producción de frutas conveniente. Se debe evitar el exceso del tamaño y de la carga de frutas para la producción de un melocotón precoz, de modo a no limitar el rendimiento, ni la calidad de las frutas respectivamente.

Francia / Prunus persica / poda / crecimiento / producción / fruto / calidad 